Svitlana Ivashnova

ORCID iD 0000-0002-4805-007x

$\mathrm{PhD}$ in Pedagogy, Associate Professor, Deputy Director of the Institute of In-Service Training, Borys Grinchenko Kyiv University, 22 a P. Tychyny Ave, 02152 Kyiv, Ukraine, s.ivashnova@kubg.edu.ua

\title{
HOW TEACHERS CHOOSE TRAINING COURSES. EMPIRICAL RESEARCH RESULTS
}

The article presents the results of a study of individual strategies for choosing training courses by teachers of general secondary education institutions. The article substantiates the choice of research methods and means for processing the results; describes the methodology for preparing an in-depth interview guide, its conduct, and analysis. The experiment results confirmed the interconnection between the level of demonstration of the extrinsic negative element of motivation for professional development and the Yanis coefficient calculated from the data of the content analysis of the in-depth interview.

In the process of research, the educational request of teachers, which is mainly focused on updating methods of action, is specified, which indicates (whether conscious ornot) the insufficient effectiveness of traditional professional technologies.

The identified selection strategies (focusing on the opinion of significant individuals and accounting for characteristics of professional activity) should be considered not only when developing new training courses, but also when promoting them at the educational services market. The research team prepared relevant recommendations for the developers.

Based on the results of the study, the methodological recommendations were developed for the system of postgraduate teacher education. The experiment, which is conducted in 22 educational institutions in Kyiv (Ukraine) and covers more than 1,750 teachers, requires verification in other conditions (small schools in remote regions, regional and district centres) since in the program it is not highlighted the impact of the megalopolis on the activity of teachers, and other local factors that may be significant.

Keywords: advanced training; educational services market; in-depth interviews; motivation; professional competence; selection strategy.

https://doi.org/10.28925/1609-8595.2020.4.4

Introduction. The requirements of the society to the content and quality of the educational system are regularly updated, which causes changes in the activity of teachers and heads of educational institutions. Decentralization, diversification and demonopolization of the postgraduate teacher educational system initiate the formation and development of many new competencies both in school teachers and school administrators and in scientific-pedagogical employees and teachers providing educational services related to the professional development of teachers. From January 1, 2020, pedagogical and scientific-pedagogical employees in Ukraine can carry out advanced training based on the free choice of place, content, forms and terms.

Such a right is assigned to them under Article 59 of the Law of Ukraine «On Education» (2019), and the procedure for advanced training is determined by a resolution of the Cabinet of Ministers of Ukraine (2019).

The general information background around teachers' activity is defined as mostly negative not only by teachers but also by parents of pupils, despite the numerous initiatives aimed at restoring the professional reputation of teachers. At the same time, society has a high level of expectations related to the reform of the educational system in Ukraine. Such circumstances surely impress the professional activity of teachers, their attitude to transformations, the results of professional development, and the like.

Scientists around the world are actively studying various aspects of the professional activities of teachers, changes in the content and forms of this activity, and respondents' attitudes to these changes.

In the context of our study, we consider as interesting the research of Israeli scientists (BenAsher, 2019) devoted to the study of awareness and reception of changes in the activities of teachers of pedagogical colleges; the scientific investigation of the Iranian scientist (Mohamadi Zenouzagh, 2019), which focuses on the analysis of the impact of the summative and formative assessment of teachers' professional 
competence (online learning); study of the results of a multi-year professional learning program by a group of scientists from the USA (Collins, Cavagnetto, 2019). The experience of educators was the subject of research by Hawaiian scholars (Le, Alefaio, 2019), who conducted a content analysis of teachers' thoughts on attention to their well-being and psychological state. One of the leading tools used in this and other studies is the content analysis of respondents' statements, the technology of which is described both in the mentioned works and in other scientific sources (Kolikant, 2019; Tomé, Herrera, Lozano, 2019; Shoshani, Eldor, 2016).

A study of the publications of Ukrainian scientists led to the conclusion that the problem of predicting the behaviour of teachers as consumers of educational services did not attract proper attention, despite the intensification of scientific research related to the educational services market as a whole. Besides, the terminology used by researchers also requires attention, since it significantly affects the possibility of applying the results of scientific research. One of the examples is the work of A. Antokhov (2009), who systematizes the classification features of the educational services market from different perspectives. The author's definition of educational services as «the volume of educational and scientific information that is transformed in the learning process into a certain amount of knowledge to meet the needs of individuals and legal entities in pre-school, comprehensive, vocational and vocational qualification training, re-education, and lifelong learning» (Antokhov, 2009) seems insufficient due to the introduction of a competency-based approach to the education. Besides, the service at the legislative level is defined as «a complex of the actions of the subject of educational activity, defined by law, the educational program or an agreement, that have a particular cost and are aimed at achieving of the anticipated learning outcomes by a recipient of education» (Law of Ukraine «On Education», 2019). In this case, the subjects of educational activity, under the current legislation, is «an individual or legal entity (an educational establishment, enterprise, institution, organization) engaged in educational activities» (Law of Ukraine «On Education», 2019, Section I, Art. 1).

The peculiarity of the adult education is the subjectivity of all participants in this process; while teachers, as consumers of the educational services in postgraduate teacher education, have got this subjectivity for the first time. In the previous period, they had no experience of learning on-demand in the system of postgraduate teacher education, did not have the experience of independent identification and fulfilment of this request. To avoid the possible negative consequences of teachers' training courses that do not ensure the proper development of professional competence, it is necessary to develop self-competence of teachers, which includes awareness of the content of professional competence, methods of diagnosis and selfdiagnosis of the level of manifestation of the individual components of professional competence; selection criteria for proper training courses and modules; design technology for a personal learning path; the peculiarities of adult learning.

In the educational practice, not only the processes of interiorization of particular information or methods of action take place, but also a valuable content is obtained, correlated with both the informational and the technological components. In the context of the postgraduate teacher education, such transformations occur not only with information (educational or scientific) but also with ways of action (professional technologies) and with personal settings for these meanings and operational modality (a personalitymotivational component of professional competence). Theoretically, a request for the training content can be formed under the impact of the insufficient information component, and for updating the ways of actions - in the course of low efficacy of the traditional professional technologies. The effectiveness of the training, in this case, should depend on the personality-motivational component, that is, the teacher's settings about the need for these changes and training for their implementation.

At the previous stage of the study, it was found out that the level and component composition of teachers' motivation for learning for professional development had no direct or inverse correlation with activity in the program. Not only the behaviour of teachers in the educational services market needed additional study, but also the assessment (positive and negative) of the experience of such participation.

This stage of the study aimed to identify factors that make an impact on the choice of the experiment participants of a training course (module), and the relationship between such indicators, as the assessment of the content and effectiveness of teachers' actions as subjects of educational activity, on the one hand, and the level of motivation for professional development, on the other. The so-called Yanis coefficient is the ratio of positive and negative assessments concerning some categories that describe the professional development of teachers; behaviour on the educational market; primary participation in the program for the development of professional competence of teaching staff and the image of the program as a whole.

The working hypothesis of the study suggested that the teachers' negative extrinsic motivation for professional development, significantly affects their behaviour as consumers at the market of educational services; assessment of the activities of organizations immediately providing services in the field of professional development of teachers; requirements for the organization of training courses. 
To study these assessments, the appropriate empirical study was organized - an in-depth interview followed by its content analysis. This method corresponds to the existing practice of sociological and marketing research. (See works by Bondar, Dopira, 2007; Ivanov, 2012). Comparative analysis of scientific sources that describe the application of the method of focus groups, in-depth interview and others methods (D. T. Campbell \& D. W. Fiske, 1959; J. Morse, 1991; V. Caracelli, J. Greene, 1993; A. Shoshani, \& L. Eldor, 2016; A. M. Tafzal Haque, M. Uddin, R. Easmin, \& S. Sohel, 2019; J. Premo, 2019; T. N. Le, \& D. Alefaio, 2019) and became the basis for choosing the method of indepth interview. Quantitative analysis was carried out using the Yanis coefficient (Bondar, Dopira, 2007). The obtained numerical data were compared with the results of studying the motivation of teachers to the development of professional competence to identify possible connections.

Description of the experimental group. The survey was conducted in June 2019. The selected educational institutions were positioned as successful, given the popularity recognized by parents of the pupils; quality of educational services, and rating indicators. At the same time, the educational institutions differed in terms of participation in the program, and the level of teachers' motivation for the professional development identified at the previous stage. A respondents' group of each institution consisted of 3 persons (director and 2 teachers). Director of an institution had individually chosen those teachers, who, in his opinion, matched the criteria specified beforehand. Thus, in each institution, a teacher was selected, who, according to the administration, pays considerable attention to his own professional experience and one, who does not pay enough attention to this aspect of professional activity. An analysis of the results of studying the motivation of teachers of these educational institutions ascertained that in the experimental group there are respondents with different indicators relating to the levels of external negative motivation (two people with a low, medium and high level), which is consistent with the stated purpose of the study.

All the interviews were video-recorded and consequently converted into text format. The qualitative analysis was performed with the use of the Atlas.ti program. The formula for calculating the Yanis coefficient was applied to quantify the results of the study.

Research Methodology. The application of the indepth interview method is appropriate when the question is individual preferences or difficulties, including those that have clear social models, or those, the discussion of which makes a respondent embarrassed, and the like. And more to the point, when it is necessary to make a detailed analysis of the decision-making process in a professional environment when respondents cannot tear themselves away from their professional duties for a long time. Since in our case we are talking about a situation of choice based on individual preferences, which may not correspond to those expectations that exist in the immediate professional environment, the use of the indepth interview method was considered optimal.

The developed in-depth interview guide consists of 4 blocks, each of which has a particular purpose.

Block 1. Professional development as a component of the professional-pedagogical activity. The information obtained in the block will help to identify the stability of communication strategies in the organization directly providing the services in the field of advanced training of teachers, the requirements for the organization of training courses.

Block 2. Consumer behaviour in the market of educational services in the field of postgraduate pedagogical education. The information obtained in the block will help to understand the perception of the advantages and disadvantages of actors in the market of educational services in the field of postgraduate pedagogical education, requirements for actors; risks; advantages; the image of an ideal actor.

Block 3. Primary participation in the Professional Development Program of the teaching staff of the educational institution. The information obtained in the block will help to understand the perception of the advantages and disadvantages of the professional development program for teaching staff; the reason for participating in the activities proposed by the participants in the professional development program of teaching staff; subjective assessment of the quality of the content of training courses / modules of the professional development program of teaching staff.

Block 4. The program of professional development of the teaching staff of the educational institution «as seen» by the target audience. The information received in the block will help to understand the perception of the image of the program for the professional development of teaching staff, the relevance of public information; their disadvantages and advantages; the image that is formed among representatives of the target audience.

Processing of the research results. Processing of the results was carried out in several stages (preparatory, executive, analytical), the contents of each of which are described in detail.

\section{Preparatory stage.}

1. The decryption of audio or video record of the interview. The text version should be in exact accordance with the audio recording and have all the respondent's verbal feedback, including exclamations, introductory words, parasitic words, since they are an important element of the psychological portrait and reflect one's emotional reactions to the content of the questions.

2. Development of a system of categories for analysis. The text is analyzed using specially designed codes to indicate blocks of questions and tasks according to the 
pre-defined category systems - the most common, key concepts that correspond to research tasks - «semantic units» and «accounting units». The system of categories corresponds to the system of questions in the in-depth interview guide and indicates which answers need to be found in the text.

3. Definition of semantic units for analysis. The main semantic unit of analysis is the topic or idea, which is determined according to indicators (labels) that indicate its presence in the material. After the selection of a semantic unit, the accounting unit is determined (the number of words, images, signs, etc.).

4. Development of a matrix of content analysis - the main working document with which the study is conducted. This is a system of coordinated and subordinated categories of analysis that looks like a questionnaire: each category (question) provides many features (answers) by which the text content is classified.

5. An essential element is an instruction to the encoder - a system of rules and explanations for the person who will process the decrypted texts of the indepth interview and encode (register) the specified units of analysis. The instructions accurately and unambiguously set out the encoder's actions, give an operational definition of the categories and units of analysis, the rules for coding them; provide examples from texts and provide explanations on how to proceed in contentious cases. To comply with uniform approaches to interpreting the content of a particular statement of respondents and assigning a code, the following approaches to encoding were defined:

- all categories have clear differences;

- when coding, the researcher should not be guided by the literal verbatim form of the answer, the content of the statement must be encoded;

- for each answer its category is preliminarily determined, no more than $5-7 \%$ of information belongs to the category «other»;

- to encode only that which correlates with the purpose of the in-depth interview and the objectives of the study;

- coding categories are determined by the purpose of this study and the collected material (video or audio recordings), therefore, the coding matrix can be specified in advance.

Executive stage. At the executive stage, the specified procedures were carried out for the allocation and registration of analysis units. We coded it under the matrix of content analysis directly in Atlas.ti 5.0.

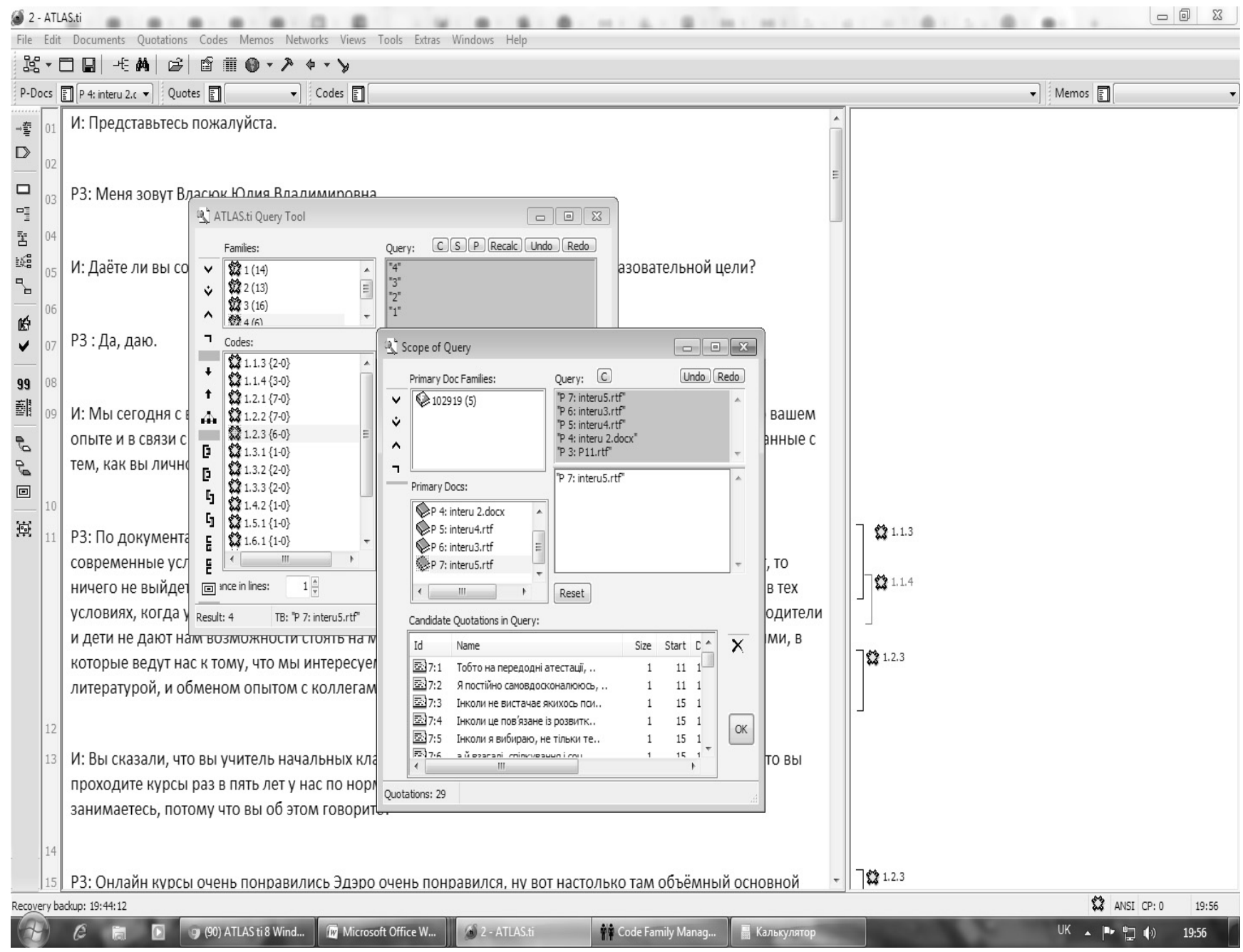


After coding completion, it was verified by another researcher to identify and correct errors. Based on the results of this stage, coding matrices were created for each interview (a total of 9 matrices).

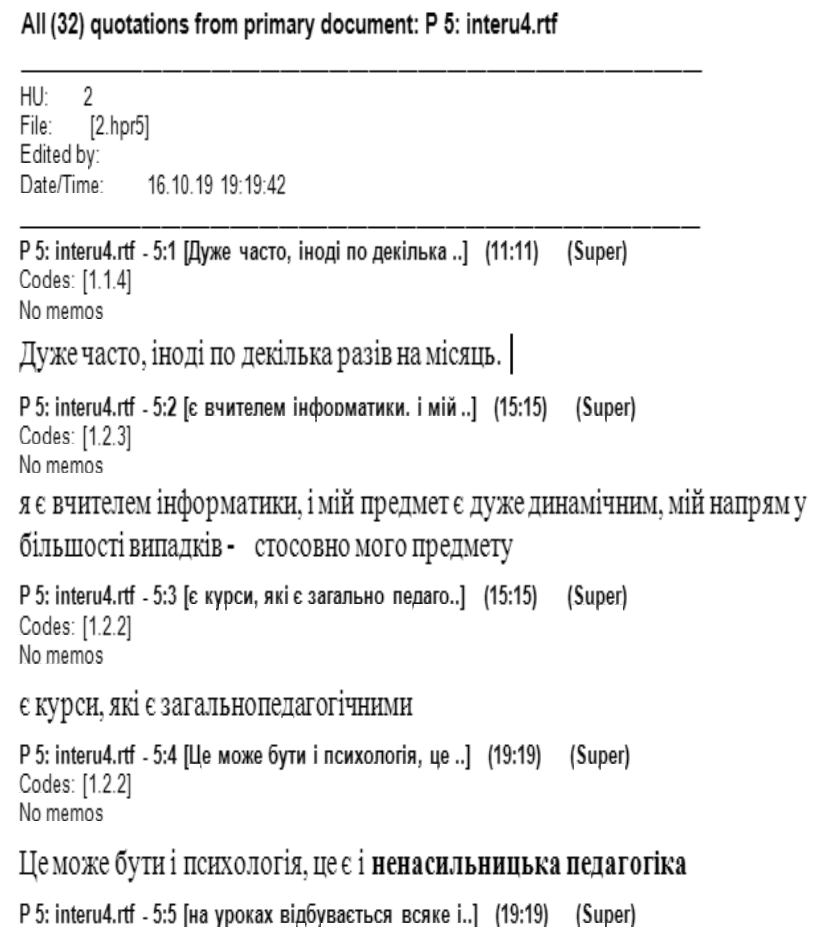

Figure 2. Fragment of the coding matrix of the interview of the $\mathbf{P} 22$ respondent (a screen image)
Data processing. The qualitative characteristics identified as a result of the study are transformed into quantitative indicators of the numerical system. The ultimate aim of the research determines the content of this stage. In our case, it was useful to calculate the Yanis coefficient, with the help of which we find out the ratio of positive and negative assessments concerning particular categories (blocks of questions).

This coefficient is calculated by the formula:

$$
\begin{aligned}
& \mathbf{C}=\frac{f^{2}-f \boldsymbol{n}}{\boldsymbol{r} \boldsymbol{n}}, \text { for cases where } \mathrm{f}>\mathrm{n}, \\
& \mathbf{C}=\frac{\boldsymbol{f n} \boldsymbol{n} \boldsymbol{n}^{2}}{\boldsymbol{r} \boldsymbol{t}}, \text { for cases where } \mathrm{f}<\mathrm{n},
\end{aligned}
$$

where $\mathrm{f}$ is the number of positive ratings, $\mathrm{n}$ is the number of negative ratings, $r$ is the number of information units reflecting the specified category, $t$ is the total volume of text analysed.

Analysis of the results of the study. The data obtained were systematized, supplemented by the results of the previous stage and arranged in the form of table 1. In addition to the results of calculating the Yanis coefficient for each respondent for each of the blocks, the indicators of the external negative motivational complex obtained at the previous stage of the experiment were entered. The inclusion of this indicator is considered necessary for a more accurate interpretation of the data for blocks 1 and 2, which are more personalized.

Table 1

The generalized results of the three stages of the study

\begin{tabular}{|c|c|c|c|c|c|c|}
\hline \multirow{2}{*}{ № } & \multirow{2}{*}{ Respondents } & \multirow{2}{*}{$\begin{array}{c}\text { ENMC } \\
\text { (level }\end{array}$} & \multicolumn{4}{|c|}{ C } \\
\cline { 3 - 7 } & & & Block 1 & Block 2 & Block 3 & Block 3 \\
\hline \multirow{3}{*}{1} & $\mathrm{P} 11$ & $\mathrm{~m}$ & 0.14 & 0.19 & 0.08 & 0.03 \\
\cline { 2 - 7 } & $\mathrm{P} 12$ & $\mathrm{~h}$ & 0.10 & 0.05 & 0.17 & -0.01 \\
\cline { 2 - 7 } & $\mathrm{P} 13$ & $\mathrm{~h}$ & 0.11 & -0.05 & 0.02 & 0.09 \\
\hline \multirow{2}{*}{2} & $\mathrm{P} 21$ & $\mathrm{~m}$ & 0.18 & 0.01 & 0.08 & 0.24 \\
\cline { 2 - 7 } & $\mathrm{P} 22$ & 1 & 0.02 & 0.06 & 0.08 & 0.07 \\
\cline { 2 - 7 } & $\mathrm{P} 23$ & 1 & 0.29 & 0.22 & 0.06 & 0.07 \\
\hline
\end{tabular}

*ENMC - extrinsic negative motivational component; 1 - low level, $\mathrm{m}$ - medium level, $\mathrm{h}$ - high level.

Interpretation of the results. At the first stage of the study, a comparative analysis of the data obtained for each educational institution separately was carried out. Presented in the form of graphs (Fig. 3), the results of the in-depth interview of school № 1 (numbering according to table 1) are quantified and showed that the estimates of all three respondents are as close as possible to the block of questions № 4 regarding the image of the experimental program for the development of professional competence of teaching staff. At the same time, maximum discrepancies were recorded in statements directly related to the behaviour of respondents in the educational services market (block 2). This educational institution is characterized by a high level of extrinsic negative motivation for professional development among $68 \%$ of teachers, however, in those respondents who directly participated in indepth interviews, the ratings for block 1 (professional development) are more positive and have differences between 0.01-0.04 (table 1). 


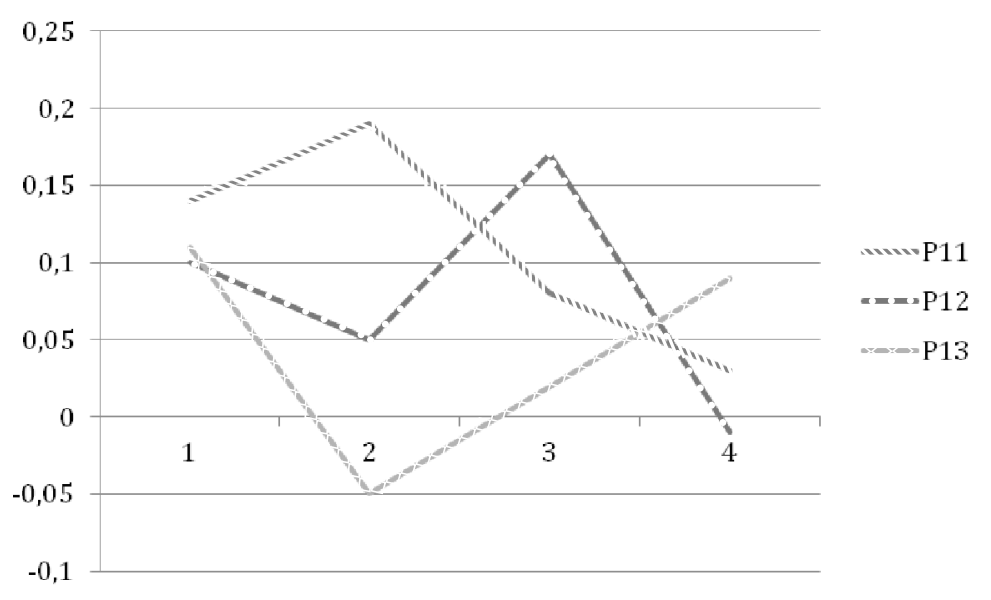

Figure 3. The results of the calculation of the Yanis coefficient for educational institution № 1

Similarly, we analysed the data for school № 2 (numbering according to table 1). For respondents from this educational institution, the estimates related to block 3 are as close as possible (primary participation in the program of development of professional competence of the teaching staff of the educational institution). At the same time, the maximum discrepancy is observed in assessments of the issues provided for in block 1 (strategies for contacting the organization that directly provide services in the field of advanced training of teachers, requirements for training organizing at courses.

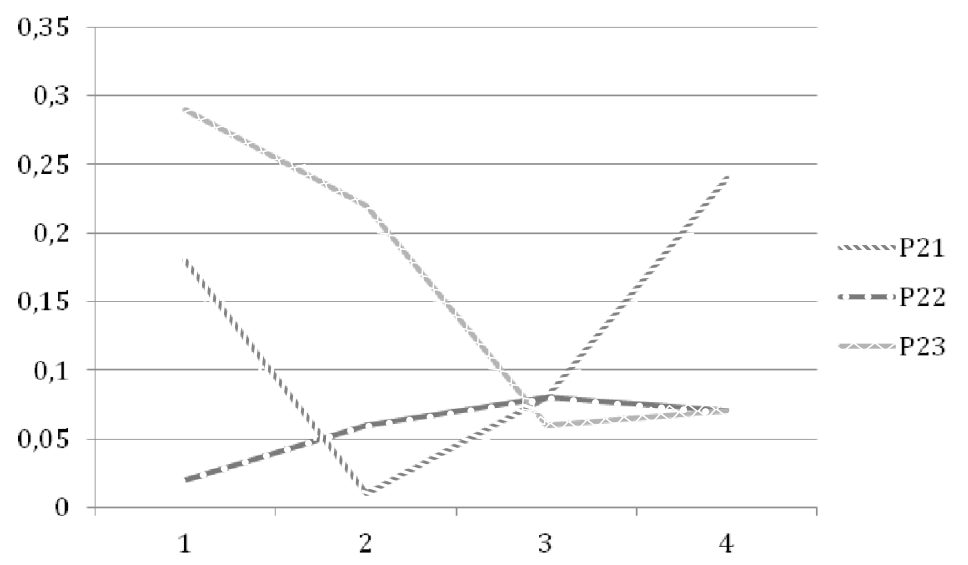

Figure 4. The results of the calculation of the Yanis coefficient for educational institution № 2

The data obtained as a result of quantification, showed significant differences both in the assessments of the heads of educational institutions (P11 and P21, respectively) and in the evaluations of teachers who were classified by the leaders as the most active participants in professional development events (P12 and P22) and the least active ones (P 13 and $\mathrm{P} 23)$.

Let us dwell in more detail on the data obtained for the so-called «Active Participants» (P12 and P22).

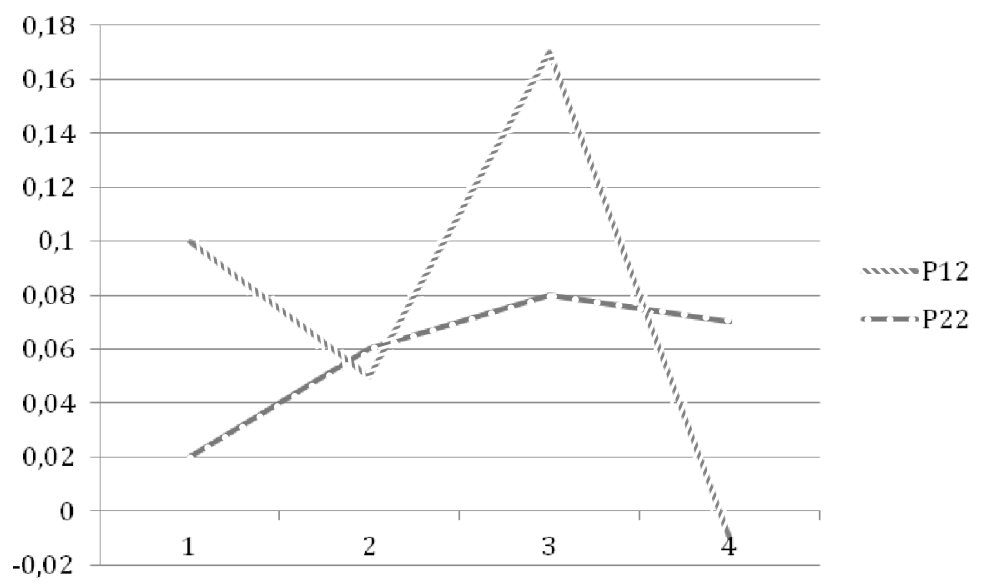

Figure 5. Results of calculations of the Yanis coefficient for respondents P12 and P22 («Active Members») 
The closest data were the ones for block 2 (behaviour in the educational services market), significant differences were recorded for the other three blocks, while the most negative assessments for block 4 of the P12 respondent concerned the possibility of transforming one's own experience in mastering critical thinking into professional actions. According to the respondent, there were not enough tools necessary for practical activities.

Verbal evaluations were as follows:

- A theory was given well, let's say, there was a dialogue with the audience, but due to lack of time, because everyone was in a hurry to go home, this part, the practical, most important part, is .... we will say this .... less.

- If we are already talking about professional growth and the application of methods in practice, I would like more specifics, perhaps in a thesis form, the theory and training of these exercises. It was not enough.

These statements testify, first of all to the need of this teacher in practical «take-and-do» tools and the use of implicitly negative assessments.

The quantified data for respondents P13 and P23 («least active») are presented in the form of graphs in Fig. 6.

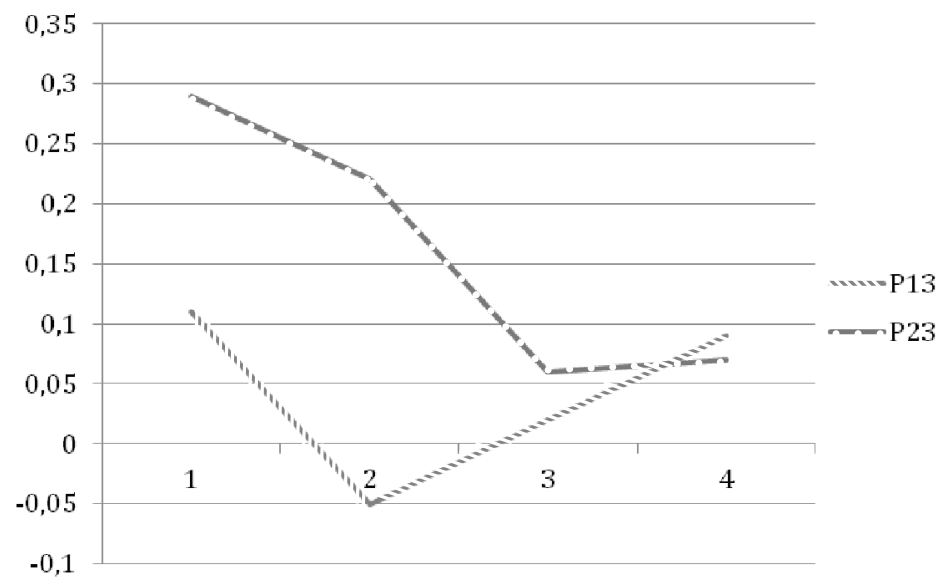

Figure 6. The quantified data for respondents P13 and P23 («The least active participants»)

The common trends (higher indicators of the Yanis coefficient for block 1 followed by a parallel decrease) show the similarity of inclinations in evaluating the results of appeal to the organization directly providing training services for teachers; requirements for the organization of training courses and the perception of the advantages and disadvantages of actors in the market of educational services in the field of postgraduate teacher education. At the same time, there is a noticeable difference in assessing the effectiveness of these requests, which, in our opinion, is the result of a critical rethinking of personal experience and the presence of respondents' stable position regarding the optimal content, forms and methods of teaching teachers in the system of postgraduate teacher education. Such conclusions are supported by the content of the judgments of the respondents. The P13 respondent selects as leading the criteria «interesting» and «necessary for work»:

- I can find on the net both methodological innovations and lesson developments and anything that interests me (P13);

- In any case, I already have an established work style, I am critical of the information that is on the network and can select what I am interested and necessary (P13).

Respondent P23 also chooses courses based on personal interests:

And perhaps some words are completely unknown to me, they cause interest in this way. And so I choose them. What is it? I want to learn something new.

However, he prefers courses focused on the formation of life competencies, for example:

- Sometimes I choose something that is not related to pedagogy ... communication and society, cultural direction, artistic direction - such a very wide range are... such and modules and classes. So ... and choose;

- Sometimes this is due to the development of information technology.

However, it does not exclude a focus on needs for both respondents:

- If it is what I supposedly need in the courses, but it is not for practical use, I refuse (P13);

- there is on the eve of certification, in this certification period, we choose the modules, courses that are needed (P23).

If we compare the data (Fig. 7) that relate to the heads of educational institutions, it is noticeable that the ratio of positive and negative assessments is identical for block 3 - an assessment of the advantages and disadvantages of the professional development program for teaching staff; the reason for participating in the activities proposed by the participants in the professional development program of teaching staff; subjective assessment of the quality of the content of training courses/modules of the professional development program of teaching staff. 


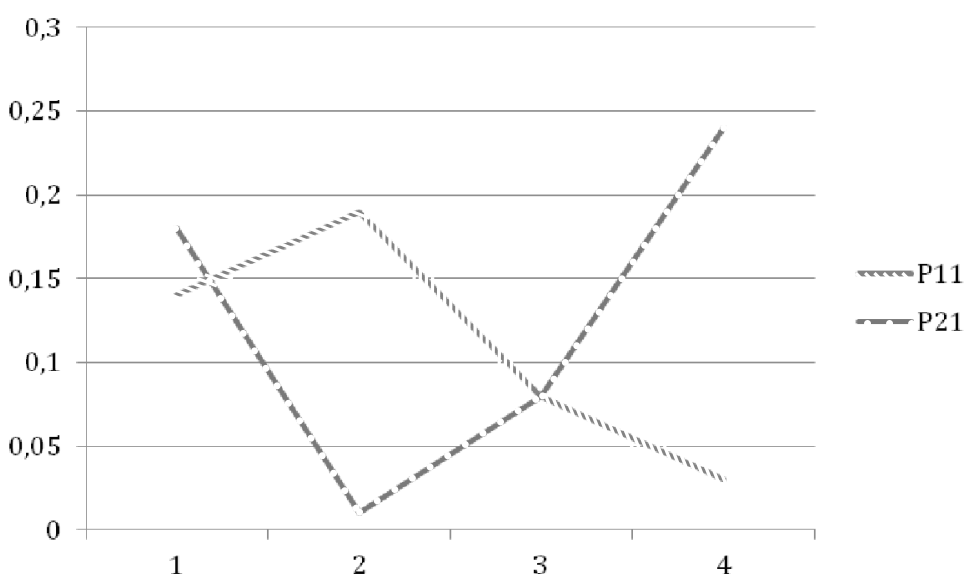

Figure 7. Results of calculation of Yanis coefficient for the heads of educational establishments 1 ra 2

Verbally, school heads evaluated the program (block 3 ) in the following terms:

- It is convenient for you;

- ... but we must remember that they chose this course, they had the opportunity to choose or not to give because everything happens only voluntarily (P11);

- Well, you can't force it, everything should be voluntary, only then there will be results, but how else? (P11);

- We choose, first of all, based on our own needs. For example, we had training on team building - this was relevant for our team (P21);

- Because we use vacation time very effectively (P21).

The most noted disagreements were recorded in the assessments regarding blocks 2 and 4. Since the information in block 2 allows us to understand the perception of the individual respondents of the advantages and disadvantages of actors in the market of educational services in the field of postgraduate teacher education, such discrepancies are understandable, since each of the respondents formed an idea about what should be the person or organization that provides the appropriate services. Significant differences in the data obtained for block 4 reflect, in our opinion, the experience of participating in the program (for school 1 - one year, for school $2-4$ years) and the effectiveness of this participation.

Since one of the objectives of the study was to identify the factor that mostly influences the decision to choose one or another training course, all the statements of respondents on such an impact were separately analysed. An analysis of the responses of teachers showed that there is a clear difference associated with the educational institution. So, for two respondents of school 1 (P11 and $\mathrm{P} 12$, that is, a director of an educational institution and an active teacher), more relevant factors are the feedback of colleagues/acquaintances/ significant persons that the course is interesting and useful; while for all representatives of school 2, it is more significant focusing on one's professional needs and difficulties/ situations at the workplace.

It is noteworthy that focusing on one's own professional needs is the leitmotif of the interview of the respondent P13 («the least active»). A possible reason for the low activity of this respondent may be the negative previous experience of training in the system of postgraduate teacher education, but the respondent is ready to review his assessments and approaches, about which the statements say as follows:

- You need to change something, even if you don't want to;

- Therefore, of course, it is necessary;

- You need to improve yourself, the 21st century ...

The comparison of quantified assessments with the results of studying respondents' motivation for professional development allows ascertaining that a high level of manifestation of the external negative component of motivation can be associated with negative indicators of the Yanis coefficient (Table 1).

It means that the personal settings of a teacher may not be reflected in the level of activity; however, they can affect the assessment of the effectiveness of professional development even if the strategies of behaviour as a consumer of educational services differ significantly.

Conclusions. The objective of this empirical study has been fully implemented, which indicates that the tools have been appropriately selected and to ensure the correctness of its application at all stages. In the process of research, the educational request of teachers, which is mainly focused on updating methods of action, is specified, which indicates (whether conscious or not) the insufficient effectiveness of traditional professional technologies.

For initiators of the research, information about the process allowing teachers to choose a training course and factors influencing this choice is useful. The identified selection strategies (focusing on the opinion of significant individuals and accounting for characteristics of professional activity) should be considered not only when developing new training courses, but also when promoting them at the educational services market. The research team prepared relevant recommendations for the developers.

The study, the results of which are presented in this article, is not comprehensive and exhaustive. The tasks concerning the research of the behaviour of teachers as consumers of educational services can be 
solved, provided that the results of scientific research are planned, implemented and summarized, aimed at studying changes in the educational needs of teachers during their professional lives; comparing the nature and dynamics of educational needs of teachers in different countries and educational systems; the impact of international organizations and changes in the national educational policy on the content and conditions for the implementation of educational requests of teachers; the study and comparative analysis of professional biographies of teachers in the context of the development of professional competence and the like. Such studies are focused on a longer period, require additional funding, international collaboration and the like.

\section{References}

Ben-Asher, S. (2019). Teaching and research: Identity representations among teacher-education faculty members, decades after an institutional change. Journal of Experimental Education, 87 (4), 680-695. 10.1080/00220973.2018.1543642

Breitmayer, B. J. (1993). Triangulation in Qualitative Research: Evaluation of Completeness and Confirmation Purposes. IMAGE: Journal of Nursing Scholarship, 25 (3), 235-257. https://doi.org/10.1111/j.1547-5069.1993. tb00788.x

Campbell, D. T. \& Fiske, D. W. (1959). Convergent and discriminant validation by the multi-trait-multi-method matrix. Psychological Bulletin, 56, 81-105. https://doi.org/10.1037/h0046016

Caracelli, V., Greene, J. (1993). Data Analysis Strategies for Mixed-Method Evaluation Designs. Educational Evaluation and Policy Analysis, 15 (2). https://doi.org/10.3102/01623737015002195

Collins, L., Cavagnetto, A., Ferry, N., Adesope, O., Baldwin, K., Morrison, J., \& Premo, J. (2019). May I have your attention: An analysis of teacher responses during A multi-year professional learning program. Journal of Science Teacher Education, 30 (6), 549-566. 10.1080/1046560X.2019.1589846

Kolikant, Y. B.-D. (2019). Adapting school to the twenty-first century: Educators' perspectives. Technology, Pedagogy and Education, 28 (3), 287-299. 10.1080/1475939X.2019.1584580

Le, T. N., \& Alefaio, D. (2019). Hawaii educators' experiences in a professional development course on mindfulness. Professional Development in Education, 45 (4), 627-641. 10.1080/19415257.2018.1474485

Mohamadi Zenouzagh, Z. (2019). The effect of online summative and formative teacher assessment on teacher competences. Asia Pacific Education Review, 20 (3), 343-359. 10.1007/s12564-018-9566-1

Morse, J. (1991) Approaches to Qualitative-Quantitative Methodological Triangulation. Nursing Research, 40 (1), 120-128. 10.1097/00006199-199103000-00014

Recommendation of the European Parliament and of the Council of 18 December 2006 on key competences for lifelong learning. http://eur-lex.europa.eu/LexUriServ/LexUriServ.do? uri=OJ:L:2006:394:0010:0018:EN:PDF

Shoshani, A., \& Eldor, L. (2016). The informal learning of teachers: Learning climate, job satisfaction and teachers' and students' motivation and well-being. International Journal of Educational Research, 79, 52-63. 10.1016/j. ijer.2016.06.007

Tafzal Haque, A. M., Uddin, M., Easmin, R., \& Sohel, S. (2019). Job Satisfaction and Citizenship Behavior: A Mediating Effect of Organizational Commitment. Organizacija, 52 (3), 236-249. https://doi.org/10.2478/ orga-2019-0015

Tomé, M., Herrera, L., \& Lozano, S. (2019). Teachers' opinions on the use of personal learning environments for intercultural competence. Sustainability, 11 (16). 10.3390/su11164475

Yanchuk, V. (1999). Methodological triangularity approach to cross-cultural phenomenon's analysis / In Sim Q. E., Tanzer N. K. (Eds.), Cultural diversity and European integration, Abstracts of Joint European Conference of International Association for Cross-Cultural Psychology and the International Test Commission, University of Graz, Austria, June 29 - July 2, 1999 (pp. 134-135). Karl-Franzes Univeršitat Press.

Antokhov, A. A. (2009). Rynok osvitnikh posluh u svitli klasychnoho ta novitnikh pidkhodiv do doslidzhennia [The market of educational services in the light of classical and modern approaches to research]. Rehionalna ekonomika, 1, 251-259. http://nbuv.gov.ua/UJRN/regek_2009_1_33

Bondar, V. S., Dopira, M. A. (2007). Rozghliad metodu kontent-analizu z pohliadu kilkisno-yakisnykh tekhnik provedennia [Reviewing of method of content-analysisin the context of quantitative and qualitative methods of realization]. Naukovi zapysky NaUKMA, 70 (Sotsiolohichni nauky), 17-26.

Zakon Ukrainy «Pro osvitu» [The Law of Ukraine On Education] (2017). https://zakon.rada.gov.ua/laws/show/2145-19

Ivanov, O. V. (2012). Kilkisny i kontent-analiz: problema kontekstu [Quantitative content analysis: a problem of context]. Visnyk Kharkivskoho natsionalnoho universytetu imeni V. N. Karazina. Seriia: Sotsiolohichni doslidzhennia suchasnoho suspilstva: metodolohiia, teoriia, metody, 30 (999), 95-99.

Poryadok pidvishennya kvalifikaciyi pedagogichnih i naukovo-pedagogichnih pracionikiv. Postanova Kabinetu Ministriv Ukrayini vid 21 serpnya 2019 r. № 800 [The order of advanced training of pedagogical and scientificpedagogical workers. Resolution of the Cabinet of Ministers of Ukraine of August 21, 2019 № 800]. https:// zakon.rada.gov.ua/laws/show/800-2019-\%D0\%BF\#Text 


\section{Література}

Ben-Asher S. Teaching and research: Identity representations among teacher-education faculty members, decades after an institutional change. Journal of Experimental Education. 2019. № 87 (4). P. 680-695. DOI: 10.1080/00220973.2018.1543642

Breitmayer B. J. Triangulation in Qualitative Research: Evaluation of Completeness and Confirmation Purposes. IMAGE:Journalof Nursing Scholarship.1993.№ 25(3).P.235-257. DOI:https://doi.org/10.1111/j.1547-5069.1993. tb00788.x

Campbell D. T. \& Fiske D. W. Convergent and discriminant validation by the multi-trait-multi-method matrix. Psychological Bulletin. 1959. № 56. P. 81-105. DOI: https://doi.org/10.1037/h0046016

Caracelli V., Greene J. Data Analysis Strategies for Mixed-Method Evaluation Designs. Educational Evaluation and Policy Analysis. 1993. № 15 (2). DOI: https://doi.org/10.3102/01623737015002195

Collins L., Cavagnetto A., Ferry N., Adesope O., Baldwin K., Morrison J., \& Premo J. May I have your attention: An analysis of teacher responses during A multi-year professional learning program. Journal of Science Teacher Education. 2019. № 30 (6). P. 549-566. DOI: 10.1080/1046560X.2019.1589846

Kolikant Y. B.-D. Adapting school to the twenty-first century: Educators' perspectives. Technology, Pedagogy and Education. 2019. № 28 (3). P. 287-299. DOI: 10.1080/1475939X.2019.1584580

Le T. N., \& Alefaio D. Hawaii educators' experiences in a professional development course on mindfulness. Professional Development in Education. 2019. № 45 (4). P. 627-641. DOI: 10.1080/19415257.2018.1474485

Mohamadi Zenouzagh Z. The effect of online summative and formative teacher assessment on teacher competences. Asia Pacific Education Revier. 2019. № 20 (3). P. 343-359. DOI: 10.1007/s12564-018-9566-1

Morse J. Approaches to Qualitative-Quantitative Methodological Triangulation. Nursing Research. 1991. № 40 (1). P. 120-128. DOI: 10.1097/00006199-199103000-00014

Recommendation of the European Parliament and of the Council of 18 December 2006 on key competences for lifelong learning. URL: http://eur-lex.europa.eu/LexUriServ/LexUriServ.do?uri=OJ:L:2006:394:0010:0018:EN:PDF (дата звернення: 7.11.2020).

Shoshani A., \& Eldor L. The informal learning of teachers: Learning climate, job satisfaction and teachers' and students' motivation and well-being. International Journal of Educational Research. 2016. № 79. P. 52-63. DOI: 10.1016/j. ijer.2016.06.007

Tafzal Haque A. M., Uddin M., Easmin R., \& Sohel S. Job Satisfaction and Citizenship Behavior: A Mediating Effect of Organizational Commitment. Organizacija. 2019. № 52 (3). P. 236-249. DOI: https://doi.org/10.2478/orga2019-0015

Tomé M., Herrera L., \& Lozano S. Teachers' opinions on the use of personal learning environments for intercultural competence. Sustainability. 2019. № 11 (16). DOI: 10.3390/su11164475

Yanchuk V. Methodological triangularity approach to cross-cultural phenomenon's analysis. Sim Q. E., Tanzer N. K. (Eds.). Cultural diversity and European integration, Abstracts of Joint European Conference of International Association for Cross-Cultural Psychology and the International Test Commission, University of Graz, Austria, June 29 - July 2, 1999. Graz: Karl-Franzes Univeršitat Press, 1999. P. 134-135.

Антохов А. А. Ринок освітніх послуг у світлі класичного та новітніх підходів до дослідження. Регіональна економіка. 2009. №1. С. 251-259.

Бондар В. С., Допіра М. А. Розгляд методу контент-аналізу з огляду кількісно-якісних технік проведення. Наукові записки НаУКМА. 2007. Т. 70: Соціологічні науки. С. 17-26.

Закон України «Про освіту». 2017. URL: https://zakon.rada.gov.ua/laws/show/2145-19 (дата звернення: 9.11.2020).

Іванов О. В. Кількісний контент-аналіз: проблема контексту. Вісник Харківського національного університету імені В. Н. Каразіна. Серія: Соціологічні дослідження сучасного суспільства : методологія, теорія, методи. 2012. № 30 (999). С. 95-99.

Порядок підвищення кваліфікації педагогічних і науково-педагогічних працівників. Постанова Кабінету Міністрів України від 21 серпня 2019 р. № 800. URL: https://zakon.rada.gov.ua/laws/show/800-2019\%D0\%BF\#Техt (дата звернення: 5.11.2020).

\section{ЯК ВЧИТЕЛІ ОБИРАЮТЬ НАВЧАЛЬНІ КУРСИ. РЕЗУЛЬТАТИ ЕМПІРИЧНОГО ДОСЛІДЖЕННЯ}

Івашньова Світлана, кандидат педагогічних наук, доцент, заступник директора з науково-методичної роботиІнституту післядипломної освіти,

Київський університет імені Бориса Грінченка,

пр. П. Тичини, 22 а, 02152 Київ, Україна, s.ivashnova@kubg.edu.ua

Стаття презентує результати дослідження індивідуальних стратегій вибору навчальних курсів педагогічними працівниками закладів загальної середньої освіти. У статті обгрунтовано вибір методів дослідження та засобів для обробки результатів, описана методика підготовки сценарію глибинного інтерв'ю, його проведення, аналізу. Результати експерименту підтвердили наявність зв'язку між 
рівнем прояву зовнішнього негативного компоненту мотивацій до професійного розвитку та обчисленим за результатами контент-аналізу глибинного інтервю коефіцієнтом Яніса, за допомогою якого встановлюється співвідношення позитивних та негативних оцінок по відношенню до блоків питань.

Упроцесі дослідження уточнено освітній запит педагогів (практичні інструменти для педагога, обмін досвідом, професійне спілкування), який переважно орієнтований на оновлення способів дій, що свідчить на (усвідомлену чи ні) недостатню ефективність традиційних професійних технологій.

Виявлені стратегіі вибору (орієнтація на думку значимих осіб та врахування особливостей професійної діяльності) потрібно враховувати не лише під час розроблення нових навчальних курсів, а й під час їх просування на ринку освітніх послуг. Досліднищька група підготувала відповідні рекомендацї для розробників.

За результатами дослідження розроблені методичні рекомендащіі для системи післядипломної педагогічної освіти. Експеримент, який проводиться у 22 закладах освіти в м. Києві (Україна) та охоплює понад 1750 педагогів, потребує перевірки в інших умовах (маленькі школи у віддалених регіонах, обласні та районні центри), оскільки не виокремлено вплив мегаполісу на активність педагогів у програмі та інші регіональні чинники, які можуть бути важливими.

Ключовіслова:глибинне інтерв'ю; мотивація; підвищеннякваліфікаціӥ; професійнакомпетентність; ринок освітніх послуг; стратегія вибору.

\section{КАК УЧИТЕЛЯ ВЫБИРАЮТ УЧЕБНЫЕ КУРСЫ. РЕЗУЛЬТАТЫ ЭМПИРИЧЕСКОГО ИССЛЕДОВАНИЯ}

Ивашнева Светлана, кандидат педагогических наук, доцент, заместитель директора по научно-методической работе Института последипломного образования,

Киевский университет имени Бориса Гринченко, пр. П. Тычины, 22 а, 02152 Киев, Украина, s.ivashnova@kubg.edu.ua

В статье представлены результаты исследования индивидуальных стратегий выбора учебных курсов педагогическими работниками заведений общего среднего образования. В статье обоснован выбор методов исследования и средств для обработки результатов, описана методика подготовки сценария глубинного интервью, его проведения, анализа. Результаты әксперимента подтвердили наличие связи между уровнем проявления внешнего негативного компонента мотивации к профессиональному развитию и вычисленным по результатам контент-анализа глубинного интервью коэффициентом Яниса, с помощью которого устанавливается соотношение положительных и отрицательных оценок по отношению к блокам вопросов.

В процессе исследования уточнен образовательный запрос педагогов (практические инструменты для педагога, обмен опытом, профессиональное общение), который преимущественно ориентирован на обновление способов действий, что свидетельствует об (осознанной или нет) недостаточной эффективности традиционных профессиональных технологий.

Выявленные стратегии выбора (ориентация на мнение значимых лич и учета особенностей профессиональной деятельности) нужно учитывать не только при разработке новых учебных курсов, но и во время их продвижения на рынке образовательных услуг. Исследовательская группа подготовила соответствующие рекомендации для разработчиков.

Порезультатамисследованияразработаныметодическиерекомендациидлясистемыпоследипломного педагогического образования. Эксперимент, который проводится в 22 учебных заведениях в г. Киеве (Украина) и охватывает более 1750 педагогов, требует проверки в других условиях (маленькие школь в отдаленных регионах, областные и районные центры), поскольку не выделено влияние мегаполиса на активность педагогов в программе и другие региональные факторы, которые могут быть важными.

Ключевые слова: глубинное интервью; мотивачия; повышение квалификации; профессиональная компетентность; рынок образовательных услуг; стратегия выбора. 